DOI 10.15517/rbt.v69i1.42792

\title{
Pod production, and dasometric variables, of the tree Senna spectabilis (Fabaceae) in a tropical dry forest
}

\author{
Jesús H. Duarte-Vargas ${ }^{1}$, Omar Melo ${ }^{2}$, Jairo Mora-Delgado ${ }^{1}$, Román Castañeda-Serrano ${ }^{1}$ \\ \& Henry Váquiro ${ }^{3}$ \\ 1. Departamento de Producción Pecuaria, Universidad del Tolima, Ibagué, Colombia; jhduarte@ut.edu.co; \\ jrmora@ut.edu.co; rcastaneda@ut.edu.co \\ 2. Departamento de Ciencias Forestales, Universidad del Tolima, Ibagué, Colombia; omelo@ut.edu.co \\ 3. Departamento de Producción y Sanidad Vegetal, Universidad del Tolima, Ibagué, Colombia; havaquiro@ut.edu.co
}

$$
\text { Received 04-VII-2020. C Corrected 13-XI-2020. Accepted 18-XI-2020. }
$$

\begin{abstract}
Introduction: Senna spectabilis is a multipurpose pantropical tree, used in agroforestry systems. Objective: To determine pod production $(P p)$ and their relationship with dasometric variables in S. spectabilis in the tropical dry forest. Methods: From August 2016 to February 2017, thirty trees in production stage were randomly selected. The random selection was formed of the more isolated trees from the total dispersion. The trees were monitored at the beginning and end of the study period, to determine dasometric measurements such as total height $(\mathrm{Th})$, height to the first branch $(\mathrm{Hb})$, crown height $(\mathrm{Ch})$, Stem diameter (at $0.2 \mathrm{~m}$ height from the ground) $(D b)$, crown diameter $(C d)$, and crown volume $(C v)$ measured. Pods were harvested by the researcher with cutting and height cutting tongs when their color began to change. Pearson correlations and univariate and multivariate regression analyses were performed between the dasometric variables and pod production. The potential number of trees/ha $(\mathrm{NPa})$ was calculated by determining the occlusion percentage $(\mathrm{OP})$ and the shadow area/tree $(\mathrm{Ca})$; to estimate the production potential of fruits/ha, the production of fruits/tree was multiplied by $(\mathrm{NPa})$. Results: Th was $6.16 \pm 1.23 \mathrm{~m}, \mathrm{Hb} 2.75 \pm 0.52 \mathrm{~m}, \mathrm{Ch} 3.41 \pm 0.98 \mathrm{~m}, \mathrm{Db} 20.43 \pm 4.80 \mathrm{~cm}, \mathrm{Cd} 7.46 \pm 1.20$ $\mathrm{m}$ and $C v 108.43 \pm 61.38 \mathrm{~m}^{3} /$ tree. There was a significant positive correlation between $\mathrm{Hb}, \mathrm{Cd}$, $\mathrm{Db}$, with $P p$ of $0.592^{* *}, 0.592^{* *}$, and $0.446^{*}$ respectively. $P p$ was $32.73 \pm 16.13 \mathrm{~kg} /$ tree and the dry matter production $(M S P)$ was $17.84 \pm 8.80 \mathrm{~kg} /$ tree. The result of the multivariate regression indicated that the second-order polynomial model presented best goodness of fit. $O p$ was $73.47 .92 \%$, the cup area was $49.3 \mathrm{~m}^{2} /$ tree, $C a$ was $36.2 \mathrm{~m}^{2} /$ tree, and $\mathrm{NPa}$ was 83 trees. Conclusions: The production of fresh pods/ tree in the S. spectabilis presents a potential in its availability as feed for ruminant or seed production. The potential production of pods in silvopastoral with S. spectabilis could be $2.72 \mathrm{t} / \mathrm{ha}$, and $1.64 \mathrm{t} /$ ha of dry pods, this shows the importance of trees and of pods production and nutritional contribution obtained for dry ecosystems.
\end{abstract}

Key words: pods; morphometry; models of predict; scattered trees; silvopastoral.

Duarte-Vargas, J.H., Omar Melo, Mora-Delgado, J., Castañeda-Serrano, R., \& Váquiro, H. (2021). Pod production, and dasometric variables, of the tree Senna spectabilis (Fabaceae) in a tropical dry forest. Revista de Biología Tropical, 69(1), 218-230. DOI 10.15517/rbt.v69i1.42792

Ruminants in tropical and subtropical countries satisfy most of their dietary needs with native grasses and crop residues, which are of low quality (Tikam et al., 2015). In order to overcome the lack of nutrients during the dry season, some producers supplement their animals with foliage and pods of woody species.
The scattered trees in the prairies improve the profitability of livestock farms because they offer economic benefits such as wood, poles, and high-quality nutritional supplements such as forage and pods (Camero, Ibrahim, \& Kass, 2001; Manning, Fischer, \& Lindenmayer, 2006). Besides, the possibility of 
receiving payments for environmental services, they have great potential to increase livestock production. This is due to the contribution of the animal's welfare; it favors the habitat of some species while improving the connectivity between wooded landscapes (Cadavid-Florez, Laborde, \& Maclean, 2020).

S. spectabilis (DC.) H.S. Irwin \& Barneby, is an important source of food for livestock and wildlife, mainly during the dry season. The forage nutritive value of the leaves and pods of these trees is generally higher than herbaceous plants, specifically in reference to legumes (Guariguata \& Ostertag, 2001; Harvey, Villanueva, \& Esquivel, 2011). The benefit of maintaining this type of tree in grasslands is evidenced by the traditional use of silvopastoral systems in several parts of the world (Hartel, Réti, \& Craioveanu, 2017).

Given the implementation of the S. spectabilis tree in silvopastoral systems in Colombia, the academy has been motivated to carry out research works to find out its potential. It is a pantropical tree (Lacerda et al., 2018) and has been introduced as an ornamental tree to different parts of Africa including Angola, Burundi, South Africa, and Eastern Africa (Jothy et al., 2012).

S. spectabilis has been commonly used in traditional medicine for many years. Information in the biomedical literature has indicated the presence of chemical components of medical importance, with antibacterial, anti-biofilm, antifungal, and antioxidant properties (Chukeatirote, Hanpattanakit, Kaprom, \& Tovaranonte, 2007; Torey, Sasidharam, Yeng, \& Latha, 2010; Jothy et al., 2012). It is a rapid growth, drought tolerant, termite attack resistant tree that is also able to grow in standard conditions (Namirembe, Brook, \& Ong, 2009). It is used for firewood (Tabuti, Dhillion, \& Lye, 2003) and widely for landscaping, due to the great beauty of its yellow flowers. Also, it has a great potential for degraded area restoration (Silva et al., 2010). S. spectabilis is a tree of the Fabaceae family (subfamily Caesalpiniaceae) (Pivatto et al., 2005). It is commonly used in semi-arid regions, where it is known as "cañafístula" or "cassia," as a forage for sheep and goats (Santos, Araújo, Nascimento, \& Lima, 2013).

The nutritional value of $S$. spectabilis forage has a high potential for livestock agroforestry technologies in the humid lowlands of West and Central Africa (Larbi et al., 2005). The protein, mineral, and fat content of $S$. spectabilis are high in comparison to other forage species that are native to the Brazilian Caatinga. For this reason, the plant represents a valuable nutritional resource during periods of drought (Almeida et al., 2011).

A study incorporated S. spectabilis tree pods as a supplement in the diet of ruminants (Bonilla-Trujillo, Pardo-Guzman, \& Castañeda-Serrano, 2018), which looked at the in vivo and in vitro digestibility and ruminal degradability in sheep hair fed with Angleton (Dichanthium spp.) hay-based diets. S. spectabilis pods were used at $0.6,1.2$, and $1.8 \%$ of body weight and concluded that the pods have an attractive nutritional value. It was proposed as a promising alternative for the ruminant supplementation in the tropical regions of the world. However, the lack of knowledge about the production of pods restricts its use and therefore, its diversification.

This tree annually produces large quantities of viable seeds; one kilogram corresponds to approximately 27600 seeds. Researchers obtained galactomannans with a yield of $31.6 \%$ in dry weight and suggest that the seeds can be considered as a potential source of galactomannans for the industry (Fernandes, Nakashima, \& Serra, 2004). Galactomannans are widely used in the pharmaceutical industry to control water activity, to stabilize aqueous solutions and dispersions, and for their high thickening power (Buckeridge, Dietrich, \& de Lima, 2000; Prajapati et al., 2013; Soares et al., 2015).

The knowledge of the tree architecture and dasometric measurements represents a contribution to defining criteria for harvesting and management (Beltrán-Galindo, Romero-Manzanares, Luna-Cavazos, \& García-Moya, 2017) and the design of agroforestry or silvicultural systems. The architecture of the tree canopy has significant impacts on the microclimate 
of the crop and is influenced by competition for light, water absorption and transpiration, dispersion of pollen; acquisition and location of carbon (Boudreau, 2013). This architecture also influences biophysical processes, such as photosynthesis and evapotranspiration (Van der Zande, Hoet, Jonckheere, Aart, \& Coopin, 2006; Rosell et al., 2009). An accurate description of the tree architecture leads to a better understanding of how the shape is controlled by each function (Lau et al., 2018).

Therefore, this research aimed to determine the production of pods and the architecture of the tree in the tropical dry forest, to contribute with tools that serve as a basis for management programs, and above all to contribute knowledge to generate alternatives of integral use of $S$. spectabilis into cattle farms.

\section{MATERIALS AND METHODS}

Location and climatic conditions: The present study was carried out in La Comarca farm located in Alvarado, Tolima, Colombia, (7458'14.6" WO \& 7458'14.6" W) under the following conditions: 460 m.a.s.l., annual average temperature $27.7{ }^{\circ} \mathrm{C}$, annual average precipitation $1601 \mathrm{~mm}$, relative humidity 67 $\%$, and is related to tropical dry forest weather according to Sánchez-Azofeifa et al., (2005).

Edaphic conditions: A chemical analysis of the soil was carried out to complement the information about the edaphic conditions at the study site, with the analysis made between 0 and $20 \mathrm{~cm}$ depth. The data of the chemical analysis, texture and bulk density is then presented. A chemical and soil texture analysis of the La Comarca farm was carried out by LASEREX laboratory of University of Tolima, finding: $\mathrm{pH} 5.9$, organic matter $2 \%$, texture ( $27.2 \%$ clay, $18 \%$ silt, $54.8 \%$ sand), humidity $15.2 \%$, and apparent density $1.49 \mathrm{~g} / \mathrm{cm}^{3}$ (Instituto Colombiano de Normas Técnicas y Certificación, 2014; 2018).
Sampling: The trees were sampled in eight transects of $300 \mathrm{~m} \times 4 \mathrm{~m}$ each, randomly plotted. Thirty trees free of visual defects, pests, and diseases were selected. All trees were georeferenced and labelled with their numbering directed towards the North cardinal point. The trees that were more isolated from the total dispersed trees were chosen (to avoid inter and intraspecific competition). The selected trees height was measured and it was found that $53.3 \%$ were less than $6 \mathrm{~m}$ tall, and were characterized by having had at least four harvests. While the trees greater than or equal to 6 meters were characterized by having more than four harvests, this was the criterion used to analyses the two ranges of height; $h<6 \mathrm{~m}(\mathrm{~N}=$ 16) and $h \geq 6 \mathrm{~m}(\mathrm{~N}=14)$.

Samples of leaves, flowers, and fruits were taken to the TOLI herbarium of the University of Tolima, for classification, and it was verified that they corresponded to the Senna spectabilis, number 29061 in the collection book.

Dasometric variables: Total $(T h)$ and first tree branch $(H b)$ height were measured with a graduated telescopic rod expressed in meters. Crown height $(\mathrm{Ch})$ was determined by the difference between $T h$ and $H b$ Equation 1 .

$$
C h=T h-H b(1)
$$

Stem diameter (at $0.2 \mathrm{~m}$ height from the ground): this measurement was made because the individuals of the species showed a main shaft bifurcation at a low height, using a diametric tape.

Crown diameter $(C d)$ in $\mathrm{m}$ : four crown radii were measured in relation to the cardinal points at $90^{\circ}$, with a tape measure, the radii were taken from the center of the tree to the outer edge of it, measured in vertical projections. Therefore, the cup diameter was set at twice the average of the four measured radii.

Crown volume $(\mathrm{Cv})$ in $\mathrm{m}^{3}$ : to estimate this, the shape of the tree's crown was taken into account, which corresponds to a spherical cap, 
therefore the corresponding equation was used Equation 2.

$$
\begin{gathered}
C v=\frac{1}{3} \pi C h^{2}(3 R-C h)(2) \\
\text { Where } R=\frac{r^{2}+C h^{2}}{2 C h}
\end{gathered}
$$

Where and $C h=$ crown height, $r=$ crown radius, $R=$ radius in which the spherical cap is circumscribed.

The dasometric measurements were made at the beginning and at the end of the evaluation period; the measurements were then averaged for the evaluations.

Pod production $(P p)$ : The pods that were within reach of the researcher were harvested with cutting tongs and the others with height cutting tongs. The pods were harvested when they presented a $50 \%$ color change (green to brown). In addition, the fallen pods were also collected and transported to be weighed and the total mass of the pods in $\mathrm{kg}$ of each sampled tree was obtained (the pods are harvested once a year, phenologically one harvest of pods per year is presented between the months of November to February according to DuarteVargas et al. (in press), an electronic weighing scale of $50 \mathrm{~kg}$ capacity with an accuracy of $5 \mathrm{~g}$, was used for weighing.

Dried pod production $(D P p)$ : For the determination of dried pods/tree, five samples of pod production were exposed to the sun on a cement surface to dry for a week and then weighed. With this procedure it was possible to determine the average yield by multiplying the production of pods per tree, thus obtaining the production of dried pods tree ${ }^{-1}$.

Dry matter production of pod/tree ( $D M P p)$ : To determine the dry matter of the pods, five dry matters analyzes of the dried pods were performed and the value averaged. The dry matter of the pods per tree was calculated by multiplying dried pod production by the dry matter percentage.

Tree occlusion percentage $(O p)$ : Vertical digital photographs were taken of the trees under study from the bottom up of the canopy in the early hours of the morning, to avoid sunlight interference. The images were analyzed software free (Gap light analyzer), which was designed to examine hemispheric photographs. This tool allowed estimating the percentage of occlusion through the canopy (Frazer, Canham, \& Lertzman, 1999). The tree canopy area (Ta) in $\mathrm{m}^{2}$ was estimated through Equation 3.

$$
T a=\pi * r^{2}(3)
$$

Where: $\mathrm{r}=$ average canopy radius, $r=C d / 2$.

The shadow area $(A s)$ : Equation 4 was used to determine:

$$
S a=T a * O p \operatorname{In} \mathrm{m}^{2}(4)
$$

Where: $O p=$ occlusion percentage.

The number of potential trees/ha of Senna spectabilis in a silvopastoril system: To calculate, it is taken into account that, the maximum shade to not affect the biomass production of Botrhioclhoa pertusa grass is a bush coverage of 20 to $40 \%$ (Serrano, 2013), and in tropical grasses a $30 \%$ shade (Castro, García, Mesquita, \& Couto, 1999; Andrade, Brook, \& Ibrahim, 2008), and for the calculation the number of tree/ha (Nt), Equation 5 was used:

$$
N t=\frac{3000 \mathrm{~m}^{2} / h a}{S a \mathrm{~m}^{2}}(5)
$$

Where: $3000 \mathrm{~m}^{2} / \mathrm{ha}=$ maximum shade in one hectare, $S a=$ the shadow area per tree.

Statistical analysis: Using the program IBM SSPS Statistics version 22, the analysis of the descriptive statistics, means, standard deviations, coefficient of variation of each one of the dimensional variables and pod production was carried out. A comparison analysis of the height ranges: $<6 \mathrm{~m}(\mathrm{~N}=16)$ and $\geq$ $6 \mathrm{~m}(\mathrm{~N}=14)$ was carried out for tree dasometric measurements with T-test for related variables, using the Anova $\mathrm{N}$ statistic; for unbalanced designs, with the MatLab R2019b program. Likewise, the normality of each variable with the Shapiro-Wilk tool was evaluated and based on the result and the Pearson correlation analysis was made to identify the correlation. Only statistically significant correlations with a value greater than or equal to 0.4 
were considered. If the value of the index was between: $0.4-0.5$ an average positive correlation, 0.75 a considerable positive correlation, 0.95 a very strong positive correlation, and 1 a perfect positive correlation.

A univariate regression analysis was performed for each of the variables, the dasometric measurements, and pod production, where different models (linear, exponential, logarithmic, polynomial, and potential) were tested and with the purpose of generating models that would allow estimating pod production, and also multivariate regression to evaluate with three different models. Two models were linear one, which considered first-order terms; another linear model with interactions that included first-order terms and interactions between pairs of them. A second order polynomial model was also used, which involved the first and second order terms of the variables and their interactions. The stepwise regression method was applied using the "stepwise" function of the MatLab R2007b software to univariate and multivariate regression. The models identified from the stepwise regression method included only those terms statistically significant at a $95 \%$ confidence level. The best models were selected considering the criteria of highest determination coefficient adjusted $\mathrm{R}^{2}$ adj, lowest mean: the square root of the mean square of the error (RMSE), Akaike Information Criteria (AIC) and Bayesian Information Criteria (BIC) (Kusmana, Hidayat, Tiryana, \& Rusdiana, 2018). Additionally, the confidence intervals of the parameters, the normality in the distribution of the residues through the Lilliefors test and the graph of the residuals were evaluated to rule out heteroscedasticity problems.

\section{RESULTS}

Dasometric variables in the tree $S$. spectabilis: It is observed that the variation coefficients of the tree dasometric variables: total height of the tree $(T h)$, height to the first branches $(H b)$, diameter at the base of the stem $(D b)$, and crown diameter $(C d)$ are lower concerning the variables: crown height $(C h)$, crown volume $(C v)$, pod production $(P p)$, dry pod production $(P p d)$, and dry matter of pod $(P p M S)$. Table 1 shows the basic statistics of the eight variables analyzed, $H, C h, H b, D b$, $D c, C v, P p, P p d, P p M S$.

It is observed that $S$. spectabilis has a crown height around 36.5 times the diameter at the base of the stem. Maintaining a large crown requires more energy to move nutrients and water throughout the length and width of the crown, but it has the advantage of receiving and intercepting a greater amount of light (King \& Clark, 2011). It is important to note that crown diameter is greater than height of the tree by $21.1 \%$. Also, height average tree is constituted by a $55.4 \%$ of crown length, these characteristics enable a biophysical design useful for the production of pods since the crown volume in the tree is high and it favors the interception of light, especially in trees $\geq 6 \mathrm{~m}$.

The average pod production/tree per harvest was $32.73 \mathrm{~kg}( \pm 16.13 \mathrm{SE} ; \mathrm{N}=30)$ and the average dry matter of pod/tree per harvest was $17.84 \mathrm{~kg}( \pm 8.8 \mathrm{SE} ; \mathrm{N}=30)$. It is also important to indicate the potential of the tree when fertilized. One tree that was excluded from the study and located next to a stable, absorbed nutrients from feces and reported a production of $118.76 \mathrm{~kg}$.

In the analysis of the height range of the trees regarding to the measurements of the tree dasometric variables, statistically highly significant differences were found $(\mathrm{P}<0.01)$. In regard to the height of trees, crown height, height to the first branch, crown diameter, and crown volume where the range of trees $\geq 6 \mathrm{~m}$ $(\mathrm{N}=14)$, is superior to the range of trees $<6 \mathrm{~m}$ $(\mathrm{N}=16)$. While for the variable diameter at the base of the stem, pod production, dry pod production, and dry matter pod production there were no statistically significant differences $(\mathrm{P}$ $>0.05$ ) between the ranges studied.

The performance of weight of harvested pod to weight of dry pod in S. spectabilis was $60.6 \%$, and the dry matter of the pods per tree was an average of 0.9 . 
TABLE 1

Dasometric variables of the tree S. spectabilis in tropical dry forest (Colombia)

\begin{tabular}{|c|c|c|c|c|c|}
\hline Variable & Height range & Average & Standard deviation & Minimum & Maximum \\
\hline \multirow[t]{3}{*}{ Total height of the tree $(\mathrm{m})$} & Average & 6.16 & 1.23 & 3.87 & 8.35 \\
\hline & $<6 \mathrm{~m}$ & $5.21 \mathrm{~b}$ & 0.56 & 3.87 & 5.81 \\
\hline & $6 \mathrm{~m}$ & $7.27 \mathrm{a}$ & 0.75 & 6.02 & 8.35 \\
\hline \multirow[t]{3}{*}{ Crown height (m) } & Average & 3.41 & 0.98 & 1.64 & 5.43 \\
\hline & $<6 \mathrm{~m}$ & $2.72 b$ & 0.53 & 1.64 & 3.47 \\
\hline & $6 \mathrm{~m}$ & $4.21 \mathrm{a}$ & 0.74 & 3.04 & 5.43 \\
\hline \multirow[t]{3}{*}{ Height to the first branch (m) } & Average & 2.75 & 0.52 & 1.99 & 4.16 \\
\hline & $<6 \mathrm{~m}$ & $2.49 \mathrm{~b}$ & 0.30 & 1.99 & 3.05 \\
\hline & $6 \mathrm{~m}$ & $3.06 \mathrm{a}$ & 0.55 & 2.21 & 4.16 \\
\hline \multirow[t]{3}{*}{ Diameter at the base of the stem $(\mathrm{cm})$} & Average & 20.43 & 4.80 & 10.6 & 31.1 \\
\hline & $<6 \mathrm{~m}$ & $20.18 \mathrm{a}$ & 5.38 & 10.6 & 28.15 \\
\hline & $6 \mathrm{~m}$ & $21.43 \mathrm{a}$ & 4.13 & 15.0 & 31.1 \\
\hline \multirow[t]{3}{*}{ Crown diameter $(\mathrm{m})$} & Average & 7.46 & 1.20 & 4.57 & 9.39 \\
\hline & $<6 \mathrm{~m}$ & $7.12 \mathrm{a}$ & 1.20 & 4.57 & 8.93 \\
\hline & $6 \mathrm{~m}$ & $7.92 b$ & 1.09 & 6.01 & 9.39 \\
\hline \multirow[t]{3}{*}{ Crown volume (m) } & Average & 108.43 & 61.38 & 17.63 & 271.11 \\
\hline & $<6 \mathrm{~m}$ & $70.05 b$ & 28.59 & 17.63 & 118.56 \\
\hline & $6 \mathrm{~m}$ & $153.98 \mathrm{a}$ & 57.67 & 85.83 & 271.11 \\
\hline \multirow[t]{3}{*}{ Pod production $(\mathrm{kg})$} & Average & 32.73 & 16.13 & 9.17 & 68.55 \\
\hline & $<6 \mathrm{~m}$ & $27.63 \mathrm{a}$ & 14.72 & 9.17 & 68.55 \\
\hline & $6 \mathrm{~m}$ & $39.00 \mathrm{a}$ & 15.48 & 17.93 & 61.74 \\
\hline \multirow[t]{3}{*}{ Dry pod production $(\mathrm{kg})$} & Average & 19.82 & 9.77 & 6.03 & 45.04 \\
\hline & $<6 \mathrm{~m}$ & $16.73 \mathrm{a}$ & 8.92 & 6.03 & 45.04 \\
\hline & $6 \mathrm{~m}$ & $23.62 \mathrm{a}$ & 9.38 & 11.78 & 40.56 \\
\hline \multirow[t]{3}{*}{ Dry matter of pod $(\mathrm{kg})$} & Average & 17.84 & 8.80 & 5.42 & 40.53 \\
\hline & $<6 \mathrm{~m}$ & $15.06 \mathrm{a}$ & 8.03 & 5.42 & 40.53 \\
\hline & $6 \mathrm{~m}$ & $21.26 \mathrm{a}$ & 8.44 & 10.60 & 36.50 \\
\hline
\end{tabular}

Different letters within the column for each variable indicate statistically significant differences, where * Significant correlation at level $0.05, * *$ Significant correlation at level 0.01 .

\section{Correlation between the dimensional} variables and the pod production: Table 2 presents the correlation study between the evaluated dasometric variables and pod production, where it is observed that diameter at the base of the stem, height to the first branch, and crown diameter have average positive correlation with pod production. The variable crown volume has a positive correlation from strong to very strong with height and crown volume. The crown diameter has an average to strong positive correlation with diameter at the base of the stem. The variables crown volume and height were the ones with the most positive correlations.
The average positive correlation between crown diameter with the diameter at the base of the stem and the considerable to very strong positive correlation between the total height of the tree with crown height and crown volume, indicate that they grow as the diameter at the base of the stem and height increase, respectively (Table 2). It is observed that as the tree increases in height the crown height increases and at the same time the crown volume increases. As the crown height increases, the crown diameter increases, and as the crown diameter increases, the pod production increases.

The mean positive correlation to considerable correlation between crown diameter 
TABLE 2

Pearson correlation matrix for and between measures of S. spectabilis tree dasometric variables and pod production

\begin{tabular}{lcccccc}
\multicolumn{1}{c}{ Variables } & $\begin{array}{c}\text { Total height } \\
\text { of the tree }\end{array}$ & $\begin{array}{c}\text { Crown } \\
\text { height }\end{array}$ & $\begin{array}{c}\text { Height to } \\
\text { the first branch }\end{array}$ & $D b$ & $\begin{array}{c}\text { Crown } \\
\text { diameter }\end{array}$ & $\begin{array}{c}\text { Crown } \\
\text { volume }\end{array}$ \\
Total height of the tree & 1 & 0.000 & 0.000 & - & 0.031 & 0.000 \\
Crown height & $0.914^{* *}$ & 1 & 0.001 & 0.043 & 0.001 & 0.000 \\
Height to the first branch & $0.635^{* *}$ & $0.586^{* *}$ & 1 & - & - & 0.000 \\
Diameter at the base of the stem & - & $0.372^{*}$ & - & 1 & 0.000 & 0.004 \\
Crown diameter & $0.395^{*}$ & $0.586^{* *}$ & - & $0.714^{* *}$ & 1 & 0.000 \\
Crown volume & $0.804^{* *}$ & $0.942^{* *}$ & $0.752^{* *}$ & $0.530^{* *}$ & $0.752^{* *}$ & 1 \\
Pod production & - & - & $0.592^{* *}$ & $0.446^{*}$ & $0.592^{* *}$ & - \\
\hline
\end{tabular}

Above the diagonal the values of $p$ are presented. Below the diagonal, the correlation values are presented, where * Significant correlation at level $0.05, * *$ Significant correlation at level 0.01 .

with the diameter at the base of the stem and positive considerable correlation to very strong correlation between the total height of the tree with crown height and crown volume, indicate that they grow as the diameter at the base of the stem and height increase respectively (Table $2)$. It is observed that as the tree increases in height, the crown height increases and at the same time the crown volume increases; as the crown height increases, the crown diameter increases, and as the crown diameter increases, the pod production increases.

Models to predict pods production: The best results of the univariate regression analysis between tree and pod production used the dasometric variable measurements. The findings indicate that the univariate models do not offer a good estimation of pod production. This is due to the largest $\mathrm{R}^{2}$ adj being 0.327 , between crown diameter and pod production in a logarithmic model and the measurement of height to the first branches does not allow an estimate of pod production.

The multivariate analysis with the stepped regression method allowed the generation of the linear model (equation 12), linear with interactions model (equation 13), and polynomial of second order model (equation 14). Table 3 shows the results of the goodness of fit and the results of the residue normality test.

The linear model presented a mean positive regression; the linear model with interactions and the second-order polynomial model showed a positive regression from considerable too strong with pod production. Although the pod production presents a high coefficient of variation, with multivariate models, it is possible to generate a better prediction of the pod production regarding the univariate analysis. In Fig. 1, it can be seen that the linear model with interactions and second-order polynomial model have a better distribution between the observed and estimated data. The random distribution of the data and residues indicates that there is homoscedasticity. The result of the analysis multivariate regression indicated that the second-order polynomial model presented the best goodness of fit.

Tree occlusion percentage in S. spectabilis was $73.47 .92 \%(\mathrm{CV}=10.8 \%)$, the cup area was $49.3 \mathrm{~m}^{2}$ tree $\mathrm{e}^{-1}$, the shadow area was 36.2 $\mathrm{m}^{2}$ tree $\mathrm{e}^{-1}$, the number of trees for $\mathrm{ha}^{-1}$ was 83 trees, the potential production of pods in a silvopastoral arrangement with $S$. spectabilis could be $2.72 \mathrm{t} \mathrm{ha}^{-1}$ of pods, and $1.64 \mathrm{t} \mathrm{ha}^{-1}$ of dried pods.

\section{DISCUSSION}

The specific allometric equations are convenient because tree species can differ greatly in tree architecture (Ketterings, Coe, Van Noordwijk, Ambagau, \& Palm, 2001). In general, bifurcation patterns, branching, and irregular and relatively complex crown shapes 
TABLE 3

Results of the indicators for the selection of the best model, normality test of residuals and models

\begin{tabular}{lcccccccccc}
\multicolumn{1}{c}{ Models Value } & \multicolumn{2}{c}{$\mathrm{R}^{2}$ adj } & \multicolumn{2}{c}{ RMSE } & \multicolumn{2}{c}{ AIC } & \multicolumn{2}{c}{ BIC } \\
Linear & $\mathrm{C}$ & Value & $\mathrm{C}$ & Value & $\mathrm{C}$ & Value & $\mathrm{C}$ & Total & C \\
Linear with interactions & 0.51 & 3 & 11.53 & 3 & 1730.5 & 1 & 858.9 & 2 & 9 \\
Second-order polynomial & 0.65 & 2 & 9.80 & 2 & 1737.5 & 3 & 861.7 & 3 & 10 \\
\hline
\end{tabular}

\section{Linear}

$P_{p}=-77.9285-21.4194 X_{2}+12.0138 X_{3}+15.2792 X_{5}(12)$

\section{Linear with interactions:}

$$
\begin{aligned}
& P p=-140.7030+20.6809 X_{1}-57.2227 X_{3}-94.726 X_{6}-4,8179 X_{1} X_{2}+ \\
& +0.080137 X_{1} X_{4}+-05.1371 X_{1} X_{6}-9.1285 X_{4} X_{2}+10.1057 X_{2} X_{5}+ \\
& 24.9831 X_{3} X_{6}++8.8526 X_{4} X_{5}-8.8947 X_{4} X_{6}(13)
\end{aligned}
$$

\section{Second-order polynomial:}

$$
\begin{aligned}
& P p=-51,1776-70958.1029 X_{2}-3.4269 X_{4}+70934.007 X_{5}-70890.0665 X_{6}- \\
& 675.9647 X_{1} X_{2}++1.2615 X_{1} X_{3}+676.5208 X_{5} X_{1}-681.1496 X_{1} X_{6}+ \\
& 9542.8607 X_{2} X_{3}-268.4061 X_{2} X_{4}+-11307.0328 X_{2} X_{5}+11268.4507 X_{2} X_{6}- \\
& 9536.3498 X_{3} X_{5}+9538 X_{3} X_{6}+268.289 X_{4} X_{5}+-267.4886 X_{4} X_{5}+11327.6477 X_{2}^{2}+ \\
& X_{6}^{2}(14)
\end{aligned}
$$

Lilliefors $95 \%$ test, where: $\mathrm{R}^{2}$ adj = adjusted correlation coefficient, RMSE = the square root of the mean square of the error, $\mathrm{AIC}$ statisticians $=$ Akaike information criterion, $\mathrm{BIC}=$ Bayesian information criterion, $\mathrm{C}=$ sum of the indicators. Where: $X_{1}=$ Diameter at the base of the stem, $X_{2}=$ Crown height, $X_{3}=$ Crown diameter, $X_{4}=$ Crown volume, $X_{5}=$ Total height of the tree, $X_{6}=$ height to the first branch. The model with the best fit according to the sum of the $\mathrm{R}^{2}$ adj, RMSE, AIC and BIC statistics was the second-order polynomial.
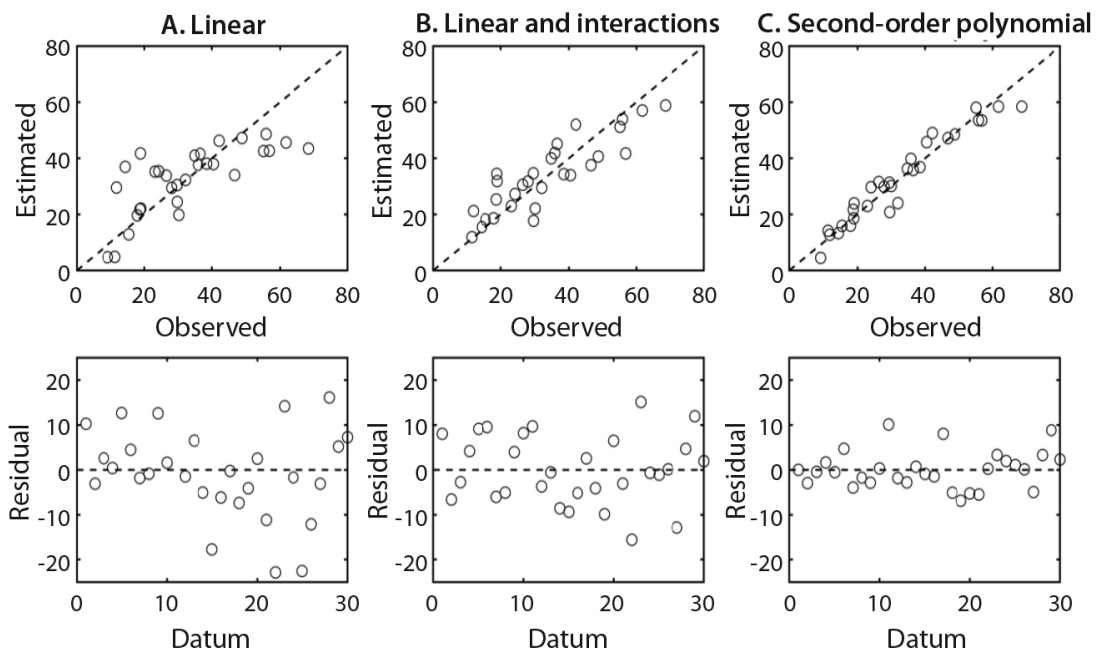

Fig. 1. Distribution of the observed and estimated data with A. linear, B. linear models with interactions and C. second-order polynomial for estimation in the production of pods in S. spectabilis. 
make it difficult to adjust correlative models between components, even in the same species.

The architecture of the trees is the result of the influence of ontogenetic and morphogenetic factors that affects all levels of organization of the organism, in each stage of its development and throughout its life period (Barthélémy \& Caraglio, 2007). Forest parameters, such as the location of the tree, the height of the tree, the number of trees, the diameter of the crown, and the tree species, are essential for the quantitative analysis of the forests (Chen, Baldocchi, Gong, \& Kelly, 2006; Koch, Heyder, \& Weinacker, 2006).

The height of the trees of $S$. spectabilis reported in this study was higher than those reported in Minas Gerais with an average of $5.9 \mathrm{~m}$ at 155 months from seed (12.91 years) (Ferreira, Bothelo, Dadive, \& Faria, 2007). Whereas in Eastern Africa, the characteristics of the tree $S$. spectabilis was a height of $6.8 \pm 0.1 \mathrm{~m}$ (Ndoli et al., 2018) and when a qualitative-quantitative analysis was performed of shrub-arboreal vegetation of the Caatinga in Teixeira, Paraiba, Brazil, the report of an average tree height in S. spectabilis was (11.3 $\%<4.05 \mathrm{~m} ; 86.1 \% 4.05 \leq \mathrm{H} \leq 6.16 \mathrm{~m}$, and $2.6 \% \geq 6.15 \mathrm{~m}$ ) (Leite, 2010). These reports of different heights may be related to the fertility of the soils and the specific environmental conditions of each place. A tree from S. spectabilis at 26 months after planting in Makoika, Malawi, had a reported height of 3.23-3.42 m (Maghembe \& Prins, 1994). The productivity of the forest site can be derived from the height and age of the dominant trees controlled by the environmental conditions (Corral, Álvarez, Ruiz, \& Gadow, 2004), especially climatic and phytogeomorphic variables (Dorner, Lertzman, \& Fall, 2002).

Reports on other members of the genus Senna shows the different characteristics between the species. In selected plantations in Colombia with a rainfall of $1200 \mathrm{~mm}$ and soils with $\mathrm{pH} 7.8$, Senna siamea were found to have arboreal spread of 3 by $3 \mathrm{~m}$, an age of 3 years, and a height average of $7.5 \mathrm{~m}$ (Francis, Lowe, \& Trabanino, 2000); Senna macranthera
(Collad.) were reported at a height of $5.8 \mathrm{~m}$ by Ferreira et al., (2007). Parolin (2001), also measured Senna reticulata (Willd.) in flood areas in the Amazon that reached a height of $12 \mathrm{~m}$. In Campinas, Brazil, other species of the fabaceae family were also researched. Centrolobium tomentosum had reported heights of $10.18 \pm 3.26 \mathrm{~m}$; Holocalyx balansae Micheli had a height of $10.26 \pm 2.6 \mathrm{~m}$ and Machaerium nyctitans (Vell.) Benth had heights of $8.84 \pm 2.9$ m (Dias, dos Santos, Maës, \& Martins, 2017).

The crown diameter in this differs from those mentioned in Eastern Africa, where the tree canopy radius was $4.7 \pm 0.1 \mathrm{~m}$ with the tree's age given by the owner as $21.9 \pm 0.9$ years (an estimated crown diameter of $9.4 \mathrm{~m}$ ) (Ndoli et al., 2018). Possibly, this result is related to the tree's age, in the case of "La Comarca farm," the estimated age of the trees does not exceed 20 years. Other research reports that $S$. reticulata trees of $4-8 \mathrm{~m}$ in height have the densest canopies, with diameters that reach 4-6 m (Parolin, 2001).

In this study, the production of pods of $S$. spectabilis was related to crown diameter and crown volume; while in Acacia pennatula, found that the production of pods is strongly related to the diameter of the tree, which at the same time is correlated with the height and coverage of the tree (Purata, Greenberg, Barrientos, \& López-Portillo, 1999). In Astrocaryum standleyanum a positive association between spatial variation in pod density and spatial densities of photodetected crowns; spatial densities of soil stems and stem diameters were found (Jansen et al., 2008).

A description of the production of pods of other tree species was made since no reports were found in the literature of pod production in S. spectabilis. In Prosopis alba, the control trees in Argentina produced $32 \mathrm{~kg}$ of pods (Ewens \& Flecker, 2010). In Prosopis chilensis, the control trees in Egypt produced $9.8 \mathrm{~kg}$ of pods (Faramawy, 2014).

Trees $S$. spectabilis with a range of height equal to or more than $6 \mathrm{~m}$ had higher averages in the dasometric variables of height, crown height, height to the first branch, and crown 
volume with respect to trees shorter than $6 \mathrm{~m}$. This is possibly because the taller trees are at a more developed stage.

It is possible that the low coefficient of determination of the univariate models is due to the fact that the variable pod production in $S$. spectabilis presents a high coefficient of variation in tree ${ }^{-1}$ pod production. This corresponds to $49.28 \%$ for the average of all trees, $39.69 \%$ for trees equal to or taller than $6 \mathrm{~m}$ and 55.25 $\%$ for trees shorter than $6 \mathrm{~m}$. On the other hand, a single dasometric measurement could hardly explain the production of pods, given that this variable is complex and depends on other dasometric measurements from the tree. The quality of the soil, the amount of rainfall, their distribution, and other factors, are all variables that affect production.

In trees dispersed in the pastures of Magdalena Medio Tolimense in Colombia, the percentage of occlusion was evaluated and it was found that Anagyris foetida presented an occlusion value of $92 \%$. Other species established in the silvopastoral systems of the dry tropics in the Fabaceae family presented values with lower occlusion. These species were Senna spectabilis, Phithecelobium dulce, Pseudosamanea guachapele, and Prosopis juliflora, with $73.4 \%, 71 \%, 64 \%$ and $63 \%$ respectively (Serrano, 2013).

An interesting aspect of the introduction of $S$. spectabilis as a scattered tree species is that by supplying the pods to cattle, the seeds are sown in fertile feces and the seedlings are not consumed by the animals. This allows diffusion of the trees in the silvopastoral system, a supplementary source of pod production, and shade for the animals in the warm environments of the tropics, an increase in seed availability for nurseries, and the generation of a potential source of galactomannans for the industry.

The production of fresh pods per tree in the S. spectabilis presents a potential in its availability as feed for ruminant or seed production.

The potential production of pods in silvopastoral with $S$. spectabilis could be $2.72 \mathrm{t} /$ ha, and $1.64 \mathrm{t} /$ ha of dry pods, this shows the importance of trees and of pods production and nutritional contribution obtained for dry ecosystems.

Ethical statement: authors declare that they all agree with this publication and made significant contributions; that there is no conflict of interest of any kind; and that we followed all pertinent ethical and legal procedures and requirements. All financial sources are fully and clearly stated in the acknowledgements section. A signed document has been filed in the journal archives.

\section{ACKNOWLEDGMENTS}

Our research is supported by the project: Innovación y gestión técnico científica para el desarrollo de la cadena ovino caprina del Tolima "INNOVIS" of Gobernación del Tolima, project registered in the Office of Research and Scientific Development of the Universidad del Tolima with the code [730115]. To the Engineer Mario Vanegas for facilitating the property.

\section{RESUMEN}

Producción de vainas, y variables dasométricas, del árbol Senna spectabilis (Fabaceae) en un bosque seco tropical. Introducción: Senna spectabilis es un árbol pantropical multipropósito, utilizado en sistemas agroforestales. Objetivo: Determinar la producción de vainas $(P v)$ y la relación con las variables dasométricas en $S$. spectabilis en el bosque seco tropical. El número potencial de árboles/ha $(N P a)$ fue calculado determinando el porcentaje de oclusión (Po) y el área de sombra/árbol (As); para calcular la producción potencial de frutos/ha, la producción de frutos/árbol fue multiplicada por $(\mathrm{NPa})$. Métodos: Desde agosto del 2016 hasta febrero de 2017, treinta árboles en etapa de producción fueron seleccionados al azar, los más aislados del total de árboles dispersos fueron seleccionados, y fueron monitoreados al inicio y al final del período de estudio, para determinar las mediciones dasométricas como la altura total $(A t)$, altura a la primera rama (Apr), altura de la copa $(A c)$, diámetro del tallo (a 0.2 m altura desde el suelo) $(D t)$, diámetro de la copa $(D c)$ y volumen de copa $(V c)$. Las vainas se cosecharon cuando su color comenzó a cambiar. Se realizaron correlaciones de Pearson y análisis de regresión univariada y multivariada entre las variables dasométricas y la producción de vainas. El número potencial de árboles/ha $(\mathrm{NPa})$ se calculó determinando el porcentaje de oclusión $(P o)$ y el área de sombra/árbol (Asa); para estimar el potencial de 
producción de las vainas/ha, la producción de vainas/árbol se multiplicó por $N P a$. Resultados: la At fue de $6.16 \pm$ $1.23 \mathrm{~m}$, Apr $2.75 \pm 0.52 \mathrm{~m}$, Ac $3.41 \pm 0.98 \mathrm{~m}$, Db $20.43 \pm$ $4.80 \mathrm{~cm}, D c 7.46 \pm 1.20 \mathrm{~m}$ y $V c 108.43 \pm 61.38 \mathrm{~m}^{3} /$ árbol. Existió una correlación positiva significativa entre $\mathrm{Apr}, \mathrm{Dc}$, $D b, P v$ de $0.592 * *, 0.592 * *$ y $0.446 *$ respectivamente. La $P v$ fue de $32.73 \pm 16.13 \mathrm{~kg}$ y la producción de materia seca $(P M S)$ fue de $17.84 \pm 8.80 \mathrm{~kg}$ /árbol. El resultado de la regresión multivariada indicó que el modelo polinomial de segundo orden presentó la mejor bondad de ajuste. El $P o$ de los árboles fue de $73.4 \% \pm 7.92 \%$, el área de copa fue de $49.3 \mathrm{~m}^{2}$ /árbol, el Asa fue de $36.2 \mathrm{~m}^{2}$ /árbol, el $\mathrm{NPa}$ fue de 83 árboles. Conclusiones: La producción de vainas frescas/árbol en el S. spectabilis presenta un potencial en la disponibilidad de alimento para los rumiantes o la producción de semillas. El potencial de producción de vainas en $\mathrm{u}$ arreglos silvopastoriles podría ser de $2.72 \mathrm{t} / \mathrm{ha}$, y 1.64 t/ha de vainas secas, esto muestra la importancia del árbol de producción de vainas y la contribución nutricional para los ecosistemas secos.

Palabras clave: vainas, morfometría; modelos de predicción; árboles dispersos; silvopastoril.

\section{REFERENCES}

Almeida, A.C.S., de Ferreira, R.L.C., Santos, M.V.F., Lira, M., Silva, J.A.A., da Lima, S.B.P., ... Sampaio, G.H. (2011). Mineral composition of arboreal and bush species occurring in pastures, in Pernambuco-Brazil. Arch Zootec, 60(231), 553-561. DOI: 10.4321/ S0004-05922011000300044

Andrade, H.J., Brook, R., \& Ibrahim, M. (2008). Growth, production and carbon sequestration of silvopastoral systems with native timber species in the dry lowlands of Costa Rica. Plant Soil, 308, 11-22.

Barthélémy, D., \& Caraglio, Y. (2007). Plant architecture: A dynamic, multilevel and comprehensive approach to plant form, structure ontogeny. Annals of Botany, 99, 375-407. DOI: $10.1093 / \mathrm{aob} / \mathrm{mcl} 260$

Beltrán-Galindo, L., Romero-Manzanares, A., LunaCavazos, M., \& García-Moya, E. (2017). Variación arquitectónica y morfológica de Hintonia latiflora (Rubiaceae) en relación a la cosecha de corteza y factores ambientales. Revista de Biología Tropical, 65(3), 900-916. DOI: 10.15517/rbt.v65i3.29444.

Bonilla-Trujillo, D., Pardo-Guzman, J., \& CastañedaSerrano, R.D. (2018). Senna spectabilis fruit on hair lambs feeding: digestibility, blood metabolites and ruminal Kinect. Ciência Animal Brasileira, 19, 1-11. DOI: 10.1590/1809-6891v19e-49895

Boudreau, M.A. (2013). Diseases in intercropping systems. Annual review of phytopathology, 51, 499-519. DOI: 10.1146/annurev-phyto-082712-102246
Buckeridge, M.S., Dietrich, S.M.C., \& de Lima, D.U. (2000). Galactomannans as the reserve carbohydrate in legume sedes. Developments in Crop Science, 26, 283-316. DOI: 10.1016/S0378-519X(00)80015-X

Cadavid-Florez, L., Laborde, J., \& Maclean, L.J. (2020). Isolated trees and small woody patches greatly contribute to connectivity in highly fragmented tropical landscapes. Landscape and Urban Planning, 196, 103745

Castro, C.R., García, R., Mesquita, M., \& Couto, L. (1999). Produção forrageira de gramíneas cultivadas sob luminosidade reduzida. Revista Brasileira de Zootecnia, 28(5), 919-927. DOI: 10.1590/ S1516-35981999000500003.

Camero, A., Ibrahim, M., \& Kass, M. (2001). Improving rumen fermentation and milk production with legume-tree fodder in the Tropics. Agroforestry Systems, 51, 157-166. DOI: 10.1023/A:1010607421562

Chen, Q., Baldocchi, D., Gong, P., \& Kelly, M. (2006). Isolating individual trees in a savanna Woodland using small footprint lidar data. Photogrammetric Engineering \& Remote Sensing, 72, 923-932. DOI: 10.14358/PERS.72.8.923

Chukeatirote, E., Hanpattanakit, P., Kaprom, A., \& Tovaranonte, J. (2007). Antimicrobial Activity of Senna spectabilis and S. tora. Journal of Plant Sciences, 2(1), 123-126. DOI: 10.3923/ijp.2010.510.514

Corral, J.J., Álvarez, J.G., Ruiz, A.D., \& Gadow, K.V. (2004). Compatible height and site index models for five pine species in El Salto, Durango (Mexico). Forest Ecology and Management, 201, 145-160. DOI: $10.1016 /$ j.foreco.2004.05.060

Dias, A.S., dos, Santos. K., Maës, F.A., \& Martins, F.R. (2017). How liana loads alter tree allometry in tropical forests. Plant Ecology, 218, 119-125. DOI: 10.1007/s1258-016-0671-0

Dorner, B., Lertzman, K., \& Fall, J. (2002). Landscape pattern in topographically complex landscapes: issues and techniques for analysis. Landscape Ecology, 17, 729-743. DOI: 10.1023/A:1022944019665

Ewens, M., \& Fleker, P. (2010). A comparison of pod production and insect ratings of 12 elite Prosopis alba clones in a 5-year semi-arid Argentine field trial. Forest Ecology and Management, 260, 378-383. DOI: $10.1016 /$ j.foreco.2010.04.030

Ferreira, WC., Bothelo, S.A., Dadive, A.C., \& Faria, J.M.R. (2007) Avaliação do crescimento do estrato arbóreo de área degradada revegetada à margem do rio Grande, na usina hidroelétrica de Camargos, MG. Revista Árvore, 31(1), 177-185. DOI: 10.1590/ S0100-67622007000100020

Faramawy, F.M.K. (2014). Response of Prosopis Chilensis to biofertilization under calcareous soil of RasSudr. 
2-Pod production. Annals of Agricultural Science, 59(2), 263-271. DOI: 10.1016/j.aoas.2014.11.014

Fernandes, C.A.D., Nakashama, T., \& Serra, G.E. (2004). Novas Contribuições ao Estudo da Galactomanana Bruta extraída de Sementes de Senna spectabilis DC. Acta Farmacéutica Bonaerense 23(3), 353-358.

Frazer, G.W., Canham, C.D., \& Lertzman, K.P., (1999). Gap Light Analyzer (GLA), Version 2.0; Imaging software to extract canopy structure and gap light transmission indices from true-color fisheye photographs, users manual and program documentation. Simon Fraser University, Burnaby, British Columbia, United States of America, \& Institute of Ecosystem Studies, Millbrook, New York, United States of America. Retrieved from https:/www.sfu.ca/rem/forestry/ downloads/gap-light-analyzer.html

Francis, J.K., Lowe, C.A., \& Trabanino, S. (2000). Bioecología de árboles nativos y exóticos de Puerto Rico y las Indias Occidentales. Río Piedras, Puerto Rico: US Department of Agriculture, Forest Service, International Institute of Tropical Forestry.

Guariguata, M.R., \& Ostertag, R. (2001). Neotropical secondary forest succession: changes in structural and functional characteristics. Forest Ecology and Management, 148 (1), 185-206. DOI: 10.1016/ S0378-1127(00)00535-1

Hartel. T., Réti, K.O., \& Craioveanu, C. (2017). Valuing scattered trees from wood-pastures by farmers in a traditional rural region of Eastern Europe. Agriculture Ecosystems and Environment, 236, 304-311. DOI: 10.1016/j.agee.2016.11.019

Harvey, C.A., Villanueva, C., \& Esquivel, H. (2011). Conservation value of dispersed tree cover threatened by pasture management. Forest Ecology and Management, 261, 1664-1674. DOI: 10.1016/j. foreco.2010.11.004

Instituto Colombiano de Normas Técnicas y Certificación. (2014). Calidad del suelo. Determinación del pH. NTC 5264. ICONTEC Internacional, Bogotá, Colombia. Retrieved from https://www.icontec.org/rules/ calidad-del-suelo-determinacion-del-ph/

Instituto Colombiano de Normas Técnicas y Certificación. (2018). Calidad de suelo. Determinación de la textura por Bouyucos. NTC 6299. ICONTEC Internacional, Bogotá, Colombia. Retrieved from https://www. icontec.org/rules/calidad-del-suelo-determinacionde-la-textura-por-bouyoucos

Jansen, P., Bohlman, S.A., Garzon-Lopez, C.X, Olff, H., Muller-Landau, H.C., \& Wright, J. (2008). Largescale spatial variation in palm fruit abundance across a tropical moist forest estimated from high-resolution aerial photographs. Ecography, 31, 33-42. DOI: 10.1111/j.2007.0906-7590.05151.x
Jothy. S.L., Torey, A., Darah, I., Choong, Y.S., Saravanan, D., Chen, Y., ... Sasidharan, S. (2012). Cassia spectabilis (DC) Irwin et Barn: A promising traditional herb in health improvement. Molecules, 17(9), 1029210305. DOI: $10.3390 /$ molecules 170910292

Ketterings, Q.M., Coe, R., Van Noordwijk, M., Ambagau, \& Palm, C.A. (2001). Reducing uncertainty in the use of allometric biomass equations for predicting aboveground tree biomass in mixed secondary forests. Forest Ecology and Management, 146, 199-209. DOI: $10.1016 / \mathrm{S} 0378-1127(00) 00460-6$

King, D.A., \& Clark, D.A. (2011). Allometry of emergent tree species from saplings to above-canopy a in a Costa Rican rain forest. Journal of Tropical Ecology, 27, 573-579. DOI: 10.1017/S0266467411000319

Koch, B., Heyder, U., \& Weinacker, H. (2006). Detection of individual tree crowns in airborne lidar data. Photogrammetric Engineering \& Remote Sensing, 72, 357-363. DOI: 10.14358/PERS.72.4.357

Kusmana, C., Hidayat, T., Tiryana, T., \& Rusdiana, O. (2018). Allometric models for above- and belowground biomass of Sonneratia spp. Global Ecology and Conservation, 15, 1-10. DOI: 10.1016/j. gecco.2018.e00417

Lacerda, R.B.M., Freitas, T.R., Martins, M.M., Texeira, T.L., da Silva, C.V., Candido, P.A... Pivatto, M. (2018). Isolation, leishmanicidal evaluation and molecular docking simulations of piperidine alkaloids from Senna spectabilis. Bioorganic \& Medicinal Chemistry, 26, 5816-5823. DOI: 10.1016/j. bmc.2018.10.032

Larbi, A., Anyanwu, N.J., Oji, U.I., Etela, I., Gbaraneh, L.D., \& Ladipo, D.O. (2005). Fodder yield and nutritive value of browse species in west African humid tropics: response to age of coppice regrowth. Agroforestry Systems, 65(3), 197-205. DOI: 10.1007/ s10457-005-0922-x

Lau, A., Bentley, L.P., Martius, C., Shenkin, A., Bartholomeus, H., Raumonen, P., ... Herold, M. (2018). Quantifying branch architecture of tropical trees using terrestrial LiDAR and 3D modelling. Trees, 32, 1219-1231. DOI: 10.1007/s00468-018-1704-1

Leite, J.A.N. (2010). Análise quali-quantitativa da vegetação arbustivo-arbórea da Caatinga em Teixei$\mathrm{ra}-\mathrm{Pb}$. (Master dissertation). Universidade Federal de Campina Grande, Brasil.

Maghembe, J.A., \& Prins, H. (1994). Performance of multipurpose trees for agroforestry two years after planting at Makoka, Malawi. Forest Ecology and Management, 64, 171-182. DOI: 10.1016/0378-1127(94)90291-7

Manning, A.D., Fischer, J., \& Lindenmayer, D.B. (2006). Scattered trees are keystone structures? implications for conservation. Biological Conservation, 132(3), 311-321. DOI: 10.1016/j.biocon.2006.04.023 
Namirembe, S., Brook, R.M., \& Ong, C.K. (2009). Manipulating phenology and water relations in Senna spectabilis in a water limited environment in Kenya. Agroforestry Systems, 75 (3), 197-210. DOI: 10.1007/ s10457-008-9169-7

Ndoli, A., Baudron, F., Sida, T.S., Schut, A.G., Heerwaarden, J.V., \& Giller, K.E. (2018). Conservation agriculture with trees amplifies negative effects of reduced tillage on maize performance in East Africa. Field Crops Research, 221, 238-244. DOI: 10.1016/j. fcr.2018.03.003

Parolin, P. (2001). Senna reticulata, a pioneer tree from Amazonian Várzea-Floodplains. Botanical Review, 67(2), 239-254. DOI: 10.1007/BF02858077

Pivatto, M., Crotti, A.E.M., Lopes, N.P., Castro-Gamboa, I., De Rezende, A., \& Viegas, C. (2005). Electrospray Ionization Mass Spectrometry Screening of Piperidine Alkaloids from Senna spectabilis (Fabaceae) Extracts: Fast Identification of New Constituents and Co-metabolites. Journal of the Brazilian Chemical Society, 16(6B), 1431-1438. DOI: 10.1590/ S0103-50532005000800023

Prajapati, V.D., Jani, G.K., Moradiya, N.G., Randeria, N. P., Nagar, B.J., Naikwadi, N.N., \& Vayira, B.C. (201). Galactomannan: A versatile biodegradable seed polysaccharide. International Journal of Biological Macromolecules, 60, 83 -92. DOI: 10.1016/j. ijbiomac.2013.05.017

Purata, S.E., Greenberg, R., Barrientos, V., \& López-Portillo, J. (1999). Economic Potential of the Huizache, Acacia pennatula (Mimosoideae) in Central Veracruz, Mexico. Economic Botany, 53(1), 15-29. DOI 10.1007/BF02860787

Rosell, J., Lloyd, J., Sanz, R., Arnó, J., Ribes-Dasi, M., Masip, J., ... Palacín, J. (2009). Obtaining the three-dimensional structure of tree orchards from remote 2D terrestrial LIDAR scanning. Agricultural and Forest Meteorology, 149 (9), 1505-1515. DOI: 10.1016/j.agrformet.2009.04.008

Silva, F.D.O., Ricarte, Í., Oliveira, D., Goretti, M., Silva, D.V., \& Braz-filho, R. (2010). Constituintes químicos das folhas de Senna spectabilis (DC) Irwin \& Barneby var. excelsa (Schrad.). Química Nova, 33(9), 1874 1876. DOI: 10.1590/S0100-40422010000900010
Sánchez-Azofeifa, G.A., Quesada, M., Rodríguez, J.P., Nassar, J.M., Stoner, K.E., Castillo, A., ... Fajardo, L. (2005). Research priorities for Neotropical dry forests 1. Biotropica, 37(4), 477-485. DOI: 10.1046/j.0950-091x.2001.00153.x-i1

Santos, M.F., Araújo, R.B., Nascimento, M.P., \& Lima, P.S. (2013). Determination of the genetic diversity among accessions of Senna spectabilis (canafístula) by using RAPD markers. Genetics and Molecular Research, 12(4), 6149-6155. DOI: 10.4238/2013

Serrano, J.R. (2013). Interacción entre cobertura arbórea y comportamiento animal durante las épocas seca y húmeda en pasturas del Magdalena Medio Tolimense. (Master dissertation), Universidad Nacional de Colombia, Colombia.

Soares, P.A.G., Seixas, J.R.P.C., Albuquerquea, P.B., Santos, G.R.C., Mourãoc, P.A.S., Barros Jr., ... Carneiro-da-Cunhaa, M.G. (2015). Development and characterization of a new hydrogel based on galactomannan and k-carrageenan. Carbohydrate polymers, 134(10), 673-679. DOI: 10.1016/j. carbpol.2015.08.042

Tabuti, J.R.S., Dhillion, S.S., \& Lye, K.A. (2003). Firewood use in Bulamogi County, Uganda: Species selection, harvesting and consumption patterns. Biomass and Bioenergy, 25(6), 581-596. DOI: 10.1016/ S0961-9534(03)00052-7

Tikam, K., Phatsara, C., Sorachakula, C., Vearasilp, T., Samiprem, S., Cherdthong, A., ... Sudekum, K.H. (2015). In vitro gas production, in vivo nutrient digestibilities, and metabolisable energy concentrations for sheep of fresh and conserved pangola grass. Small Ruminant Research, 128, 34-40. DOI: 10.1016/j. smallrumres.2015.05.002

Torey, A., Sasidharan, S., Yeng, C., \& Latha, L.Y. (2010). Standardization of Cassia spectabilis with Respect to Authenticity, Assay and Chemical Constituent Analysis. Molecules, 15, 3411-3420. DOI: 10.3390/ molecules 15053411

Van der Zande, D., Hoet, W., Jonckheere, I., Aardt, J.V., \& Coppin, P. (2006). Influence of measurement set-up of ground-based LiDAR for derivation of tree structure. Agricultural and Forest Meteorology, 141, 147160. DOI: 10.1016/j.agrformet.2006.09.007 